\title{
The Effects of Irrigation Regimes on the Yield and Water Use of Eggplant (Solanum melongena L.)
}

\author{
Serhat AYAS \\ Yenisehir İbrahim Orhan College, University of Uludag, Yenisehir, Bursa, Turkey.
}

\begin{abstract}
*Sorumlu yazar e-mail (Corresponding author e-mail):serayas@uludag.edu.tr Geliș tarihi (Received) : 31.05.2017

Kabul tarihi (Accepted): 07.06.2017

DOI : $10.21657 /$ topraksu.339835
\end{abstract}

\begin{abstract}
The general objective of this study was to specify the influence of deficit irrigation on yield for eggplant grown under unheated greenhouse condition. The area trials were conducted at the Agricultural Research Station of Yenișehir Vocational School of Uludag University in Bursa, Turkey during growing season of 2007. In the study, irrigation regimes consisted of full irrigation (1.00 K1 $)$ and three deficit irrigation treatments $\left(\mathrm{K}_{\mathrm{cp}}, \mathrm{K} 3_{\mathrm{cp}^{\prime}}\right.$ and $\mathrm{K} 4_{\mathrm{cR}}$ corresponding to $0.75,0.50$ and $0.25 \mathrm{Of}$ accumulative pan evaporation). A nonirrigated treatment ( $\mathrm{K} 5 \mathrm{cp}$ ) was also designed for control purpose. Applied irrigation water amounts were changed between 85 and $464 \mathrm{~mm}$, and water consumption were varied from 170 to $472 \mathrm{~mm}$. Eggplant yield, length, diameter, weight and dry matter were significantly influenced by irrigation water level. The highest yield averaging $62 \mathrm{t} \mathrm{ha}^{-1}$ was obtained at $\mathrm{K} 1_{\mathrm{cp}}$. Crop yield response factor $\left(\mathrm{k}_{\mathrm{y}}\right)$ for eggplant was found as 1.14. Water use efficiency (WUE) and irrigation water use efficiency (IWUE) for the $\mathrm{K} 2_{\text {cp }}$ treatment were calculated to be 13.16 and $10.63 \mathrm{~kg}$ $\mathrm{m}^{-3}$. These were the highest WUE and IWUE values. $\mathrm{K} 2_{\text {cp }}$ application (75\%) can be recommended as the most effective irrigation level for the eggplant to which drip irrigation is applied under scarce water resource and unheated greenhouse conditions.
\end{abstract}

Key words: Evapotranspiration, deficit irrigation, water use efficiency (WUE), yield and quality parameters, irrigation scheduling.

\section{Sulama Rejimlerinin Patlıcanın (Solanum melongena L.) Verim ve Su Kullanımına Etkileri}

Öz

Bu çalıșmanın amacı, ısıtmasız sera koșulları altında patıcan'ın verimi üzerinde kısıntılı sulamanın etkisini belirlemektir. Araștırma, 2007 ylında Bursa Uludağ Üniversitesi Yenișehir Meslek Yüksekokulu Tarımsal Araștırma İstasyonunda yürütülmüștür. Çalıșmada, 2 günlük sulama sıklığına karșıllık gelen A Sınıfı Buharlașma Kabından olan buharlașmanın 1.00 (K1 $\left.{ }_{c p}\right), 0.75\left(\mathrm{~K} 2_{\mathrm{cp}}\right), 0.50\left(\mathrm{~K} 3_{\mathrm{cp}}\right), 0.25\left(\mathrm{~K} 4_{\mathrm{cp}}\right)$ ve 0.00 (K5 $\left.5_{\mathrm{cp}}\right)$ $\%$ (kontrol olarak)'ı kadar patılıcana sulama suyu uygulanmıștır. Bitkiler için uygulanan sulama suyu miktarı 85 mm ile 464 mm ve bitki su tüketimi 170 mm ile 472 mm aralığında değișmiștir. Verim, boy, çap, ağırlık ve kuru madde miktarı üzerinde, sulama suyu düzeyinin etkisi önemli bulunmuștur. En yüksek verim $62 \mathrm{t}$ $\mathrm{ha}^{-1}\left(\mathrm{~K} 1_{\text {cp }}\right)$ olmuștur. Bitki verim tepki faktörü $\left(\mathrm{k}_{\mathrm{y}}\right) 1.14$ olarak bulunmuștur. Su kullanım randımanı (WUE) ve sulama suyu kullanım randımanı (IWUE) için en yüksek değerler, K2 ${ }_{\text {cp }}$ uygulaması için 13.16 ve 10.63 $\mathrm{kg} \mathrm{m}^{-3}$ olarak bulunmuștur. Su kaynaklarının yetersiz olduğu ısıtmasız sera koșulları altında damla sulama ile sulanan patlıcan için K2 cp uygulaması, en uygun su uygulama düzeyi olarak önerilebilir.

Anahtar Kelimeler: Evapotranspirasyon, su kullanım etkinliğ (WUE), verim ve kalite parametreleri, sulama planlaması. 


\section{INTRODUCTION}

As a great advancement in agricultural production (Aldrich and Barto, 1999), greenhouse technology is the best possible way for efficient use of agricultural inputs under limited agricultural area and demand for vegetables. Environmental conditions are fully or partially controlled at greenhouses covered by transparent materials to obtain maximum yield and the highest quality. Greenhouse production is steadily increasing throughout the world (Enoch and Enoch, 1989; Von Elsner et al., 2000). Turkey takes fifth place in the world in terms of greenhouse covered land (FAO, 2013). Turkey has Mediterranean type greenhouses; low-priced, unheated plastic-covered frames with soil-grown crops. Recently, crop cultivation in greenhouses is being commercially realized at more than 50 countries (Mahajan and Singh, 2006).

Ritchie and Johnson (1990) stated that irrigation scheduling prevented soil water deficiency that was caused by falling below some lower limit values in a certain crop and soil condition, moreover, irrigation scheduling enabled estimations of the latest date for irrigation and effective irrigation to abstain from harmful influences of water stress on the crops. Insufficient irrigation decreases production as giving rise to water stress on the crops, on the other hand excessive irrigation reduces productivity. Therefore, drip irrigation system is very important in irrigation scheduling.

Approaches based on evapotranspiration (BarYosef and Sagiv, 1982; Mc Neish et al., 1985; Clough et al., 1990; Hartz, 1993) or allowable soil-water depletion (Bogle et al., 1989) were mostly used to build some scheduling strategies for drip irrigation. Pan evaporation method which integrates evaporation measured from Class A pan to crop consumptive water use (CWU) is widely used method for estimating CWU. A pan coefficient $\left(K_{p}\right)$ is used to relate these two quantities. An approach based on the pan coefficient $\left(K_{p}\right)$ with no employment of complicated instrument may be considered as one of the simplest methods in irrigation scheduling. A certain estimation for $k$ is generally compulsory in the view of regional and local characteristics, soil characteristics, plant physiology and cultural applications. Yuan et al. (2003) stated that k values that were estimated for regional irrigation scheduling program remained in low level for an effective irrigation management while it should be sufficiently high to eliminate water stress which might occur in urgent and special local conditions. There could be found many studies that focused on irrigation methods using Class A evaporation pan. Some of the studies are as follows; tomato (Locascio and Smajstrla, 1996), eggplant (Ertek et al., 2006), lettuce (Yazgan et al., 2008), green bean (Büyükcangaz et al., 2008), cucumber (Ayas and Demirtaș, 2009), pepper (Demirtaș and Ayas, 2009), onion (Ayas and Demirtaș, 2009), potato (Ayas and Korukçu, 2010; Ayas, 2013) and broccoli (Ayas et al., 2011 ).

Eggplant (Solanum melongena L.) is one of the conventional crops in many tropical, subtropical and Mediterranean countries. Although there have been many researches on the influences of regulated water limitation on yield and quality parameters, relatively few number of papers related eggplant irrigation under semi-arid conditions have mentioned the relationships amongyield, vegetative growth, and physiological responses to different irrigation levels. However, some studies have been reported on eggplant irrigation in Turkey and other parts of the world (Behboudian, 1977; Graaf and Ende, 1981; Eliades, 1992; Chartzoulakis and Drosos, 1999; Ertek et al., 2002; Kırnak et al., 2002; Hamdy et al., 2002; Ertek et al., 2006;). These studies clearly exhibit that crop characteristics such as yield, fruit length, fruit weight and biomass production were highly connected with optimal amounts of irrigation water supply.

The goal of our trial was to specify the influences of different irrigation water levels on the yield, fruit diameter, length and weight and dry matter, daily and seasonal cumulative evaporation, yield response factor $\left(\mathrm{k}_{\mathrm{y}}\right)$, water use efficiency (WUE) and irrigation water use efficiency (IWUE).

\section{MATERIALS AND METHODS}

Field trials were conducted under unheated greenhouse conditions in the region of BursaYenișehir 140'15'09 "N latitude, $29^{\circ}$ 38'43"E longitude and altitude of $225 \mathrm{~m}$ above mean sea level). For experimental purposes, high tunnel type plastic covered greenhouse with the size of 8 $\mathrm{m} \times 40 \mathrm{~m}$ was built. The climate characteristics of the experiment field was hot and dry in summer and cold and rainy in winter. Total precipitation 
The Effects of Deficit Irrigation on Eggplant (Solanum Melongena L.) Yield in Greenhouse Condition O e r Q IS I

Table 1. Some of chemical and physical properties of experimental field soil.

Çizelge 1. Deneme alanının bazı kimyasal ve fiziksel özellikleri

\begin{tabular}{|c|c|c|c|c|c|c|c|c|c|c|}
\hline \multirow{2}{*}{$\begin{array}{l}\text { Soil depth } \\
(\mathrm{cm})\end{array}$} & \multirow{2}{*}{$\begin{array}{c}Y \\
\left(\mathrm{~g} \mathrm{~cm}^{-3}\right)\end{array}$} & \multirow{2}{*}{ Soil type } & \multirow{2}{*}{$\begin{array}{c}\text { Field } \\
\text { Capacity (\%) }\end{array}$} & \multirow{2}{*}{$\begin{array}{c}\text { Wilting } \\
\text { Point (\%) }\end{array}$} & \multirow{2}{*}{$\mathrm{pH}$} & \multirow{2}{*}{$\begin{array}{l}\text { Total } \\
\text { Salt (\%) }\end{array}$} & \multirow{2}{*}{$\begin{array}{c}\mathrm{CaCO}_{3} \\
(\%)\end{array}$} & \multirow{2}{*}{$\begin{array}{l}\text { Organic } \\
\text { Matter }\end{array}$} & \multicolumn{2}{|c|}{ Available $\left(\mathrm{kg} \mathrm{da}^{-1}\right)$} \\
\hline & & & & & & & & & $P$ & $\mathrm{~K}$ \\
\hline & 1.34 & & & & & & 5.67 & & & \\
\hline $30-60$ & 1.37 & SL & 17.26 & 9.98 & 8.04 & 0.051 & 8.49 & 1.39 & 1.24 & 19.52 \\
\hline
\end{tabular}

$Y$ :Unit weight of soil, SL:Sandy loam, P: Phosphorus, K: Potassium

of growth period and the average temperature of growth period for the regions where greenhouse experiments were carried out was $337.8 \mathrm{~mm}$ and $11.3^{\circ} \mathrm{C}$, respectively. The average minimum temperature was gauged as $3.6^{\circ} \mathrm{C}$ in December while the maximum temperature was gauged as $23.3^{\circ} \mathrm{C}$ in August (Anonymous, 2003). The soil of the experiment field was classified as sandy loam and soil pH ranged between 7.99 and 8.04. Some of the physical and chemical characteristics were presented in Table1.

Mankozeb and Endosulfan were sprayed to the experiment fields as a chemical drug against diseases and insect pests, and $120 \mathrm{~kg} \mathrm{ha}^{-1} 21 \%$ $\mathrm{N}$ and $120 \mathrm{~kg} \mathrm{ha}^{-1} 46 \% \mathrm{P}_{2} \mathrm{O}_{5}$ granular fertilizer was applied two weeks prior to sowing process. An additional $120 \mathrm{~kg} \mathrm{ha}^{-1} 46 \% \mathrm{~K}_{2} \mathrm{O}$ fertilizer was applied when the crops reached to height of $15 \mathrm{~cm}$. $10 \mathrm{~L}$ hal- chlorophyllous-ethyl was sprayed against insects. Transplantation date of the eggplant seedlings to the plots was 5 September 2007. Eggplant seedlings came to the harvest stage after 114 days of the planting day. Eggplants were harvested once a week and it was harvested three times. In the experiments, row and plant spacing were $0.5 \mathrm{~m} 0.75 \mathrm{~m}$, respectively. Each plot has contained 45 plants. 9 plants of middle row were harvested to prevent the water penetration from its neighboring plots (Figure 1).
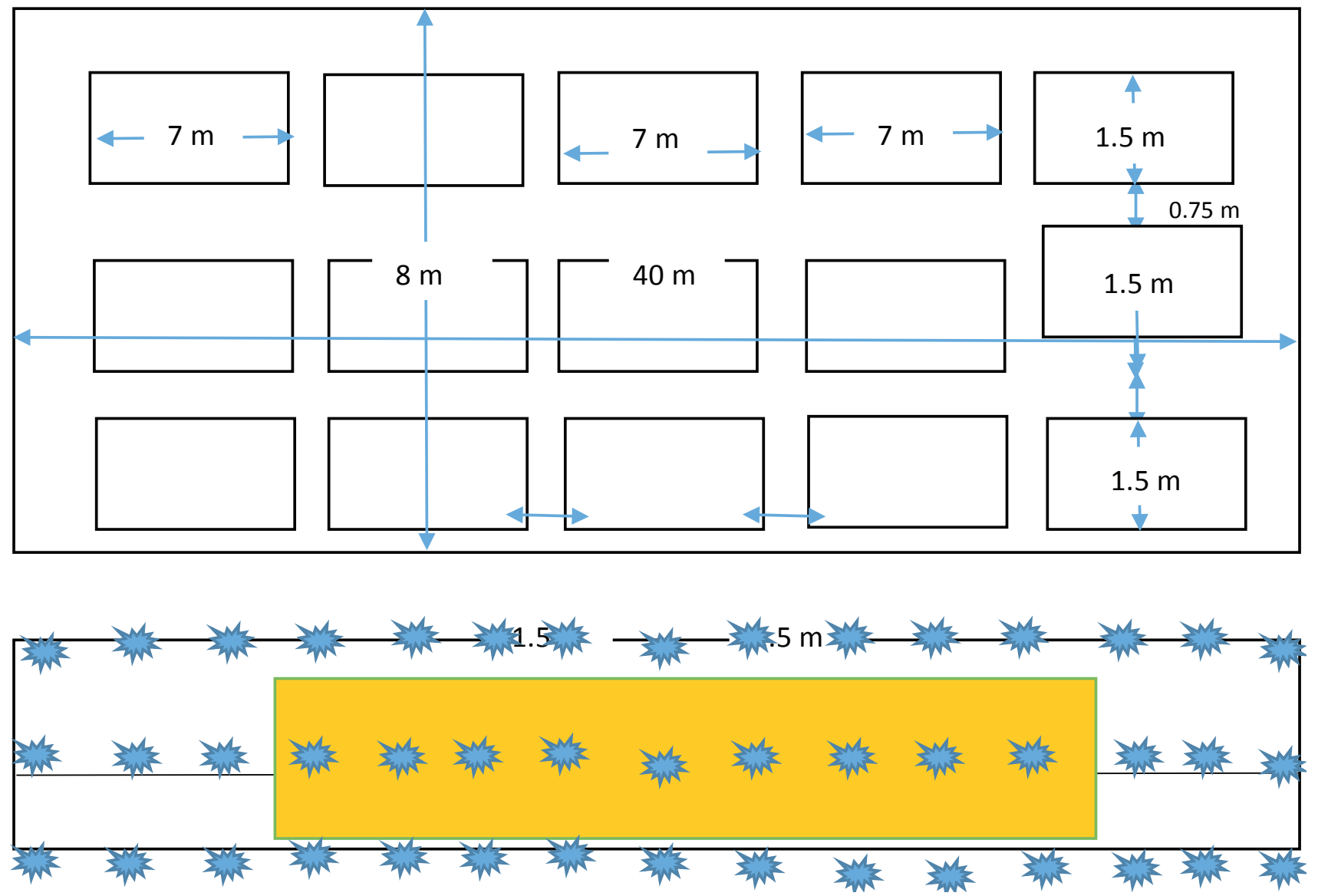

Figure 1. The order of the trial and details of parcels

Sekil 1. Deneme düzeni ve parsellerin detayları 
The length $(\mathrm{cm})$, diameter $(\mathrm{cm})$ and weight $(\mathrm{g})$ of eggplants were measured by callipers and the average of measured values was calculated. Dry matter content was determined by the separation and drying (at $65^{\circ} \mathrm{C}$ in drying oven) of fruits (two samples for each plot). . The amount of dry matter of fruits and leaves was determined by using Kjeldahl method (AOAC, 2000). The order of the trial was set as a randomized block design with 3-replication and single factor, and 5 irrigation applications were randomly distributed to each blocks. The irrigation applications were created using five different crop evaporation coefficiencies (K1 cp: 1.00, K2cp: 0.75, K3cp: 0.50, K4cp: 0.25 , K5сp: 0.00-for control purposes). The amount of irrigation water was determined using below stated equation (Doorenbos and Pruitt, 1977; Kanber, 1984):

$$
M=E_{\text {pan }} \times K_{c p} \times P
$$

Where, Ep is cumulative evaporation ( $\mathrm{mm}$ ) for 2-day irrigation frequency, $\mathrm{Kcp}$ is pan evaporation coefficiency, and $\mathrm{P}$ is the percentage of wet area. Evaporations that occurred in the 2 day irrigation frequency was measured using US Weather Bureau Class A that was held in the center of greenhouse applications and drip irrigation method was used. The amount of irrigation water was measured with flowmeter devices at the gate of each plot. The required irrigation water was supplied from a deep well (3 $L$ s-1) that was drilled in the field. Quality properties of the irrigation water were presented in Table-2. Irrigation water quality was low sodium risk and classified in C2S1 with medium level EC value.

Crop evapotranspiration (Cumulative evapotranspiration - ET ) was calculated for 2 day irrigation interval using the below stated water balance equation;

$$
E T_{c}=\left(S W C_{t 0}-S W C_{t 1}\right)+M W-D
$$

Where $\left(S W C_{t o}-S W C_{t 1}\right)$ is the change in volumetric soil water content (mm); IW (mm) and $\mathrm{D}(\mathrm{mm})$ are, irrigation water depth $(\mathrm{mm})$ and drainage $(\mathrm{mm})$ for the related period, respectively.
Prior to irrigation water applications, water content in $0.60 \mathrm{~mm}$ soil depth was determined with a gravimetric method (Lorenz and Maynard, 1980). Water content of the soil was monitored till 0.90 depth with increments of $30 \mathrm{~cm}$ depth following irrigation applications for each irrigation application. In subplots, the percolations below $0.60 \mathrm{~m}$ soil depth were omitted. In our study, the relationships between yield and ET were determined by the Stewart model (Doorenbos and Kassam, 1979):

$$
\left(1-Y_{a} / Y_{m}\right)=k_{y}\left(1-E T_{a} / E T_{m}\right)
$$

Where, Ya and ETa are actual crop yield productivity (t ha-1) and cumulative evaporation $(\mathrm{mm})$, respectively, under insufficient irrigation conditions; Ym and ETm are maximum crop yield productivity (t ha-1) and cumulative evaporation (mm) under sufficient water conditions. Yield productivity response factor of the limited irrigated eggplants was presented with ky. Water use efficiency (WUE) value was calculated to evaluate the irrigation efficiency in the applications. The two terms that are used to encourage the effective use of irrigation water in crop production phases are water use efficiency (WUE) and irrigation water use efficiency (IWUE). Water use efficiency (WUE) is calculated as the efficiency ratio of YLD to ETa and depicted as WUE = YLD / ETa (kg $\mathrm{m}^{-3}$ ). Irrigation water use efficiency (IWUE) was estimated with the below stated equation (Howell et al., 1990):

$$
\text { IWUE }\left(\mathrm{kg} \mathrm{m}^{-3}\right)=\frac{Y L D-Y L D_{\text {rainfed }}}{\operatorname{IRGA}}
$$

Where, YLD is yield value of each treatment plot ( $k g$ ha-1), YLD ${ }_{\text {rainfed }}$ is yield value from control (full irrigated) treatment plot ( $\mathrm{kg}$ ha-1), IRGA is seasonal irrigation water amount (mm). Eggplant seedlings completely grew and fruit had the yield productivity, fruit width, length and weight, color and taste characteristics to its species, 114 days (DOY $=114$ ) after plantation, i.e. in harvest season. Yield productivity and quality parameters, i.e. fruit width, length and weight and dry matter ratio,

\begin{tabular}{|c|c|c|c|c|c|c|c|c|}
\hline \multirow{2}{*}{$\begin{array}{l}\text { Water } \\
\text { source }\end{array}$} & \multirow{2}{*}{$E C_{25} \times\left(10_{6}\right)$} & $\mathrm{Na}^{+}$ & $\mathrm{K}^{+}$ & $\mathrm{Ca}^{++}$ & $\mathrm{Mg}^{++}$ & \multirow{2}{*}{$\mathrm{pH}$} & \multirow{2}{*}{ Class } & \multirow{2}{*}{ SAR } \\
\hline & & \multicolumn{4}{|c|}{$\left(m e L^{-1}\right)$} & & & \\
\hline Deep well & 715 & 2.3 & 2.56 & 9.25 & 5.7 & 7.12 & $\mathrm{C} 2 \mathrm{~S} 1$ & 0.85 \\
\hline
\end{tabular}
were evaluated for each harvest season.

Table 2. Chemical composition of irrigation water used in the experiment.

Çizelge 2. Denemede uygulanan sulama suyunun kimyasal bileșimi. 
Variance analysis was conducted with yield productivity and productivity components by using MSTAT-C (version 2.1-Michigan State University 1991) and MINITAB (Texas University, Austin) software. The significance of irrigation applications was calculated at 0.05 and 0.01 probability levels with F-test (Steel and Torrie, 1980).

\section{RESULTS}

Water applied and water used: All treatments received $85 \mathrm{~mm}$ irrigation water to refill available soil water content of $0-60 \mathrm{~cm}$ soil depth up to field capacity level following planting date. Class A pan measurements of evaporation were just started after first irrigation water application. The maximum and minimum amounts of irrigation water applied were 464 and $85 \mathrm{~mm}$ for $\mathrm{K} 1_{\mathrm{CP}}$ treatment and $\mathrm{K} 5$ cp treatment, respectively. The amount of water applied to other treatments varied from 116 to $348 \mathrm{~mm}$. An increase in seasonal evapotranspiration $\left(E_{a}\right)$ was observed with an increase at applied irrigation water. The actual evapotranspiration ranged between $170 \mathrm{~mm}$ to $472 \mathrm{~mm}$ for $\mathrm{K} 5_{\mathrm{cp}}$ and $\mathrm{K} 1_{\mathrm{cp}}$ treatments, respectively (Table 3 ).

Linear relationships between crop evapotranspiration (ETC) with yield productivity (Ya), and irrigation water (IW) with yield $\left(Y_{a}\right)$ were observed. The relationship equation is as follows; $Y_{a}=0.1489 E T_{C}-8.063$ with $R^{2}=0.99$ and $Y_{a}=$ $0.1191 \mathrm{IW}-9.3396$ with $R^{2}=98$ (Figure 2).

The highest yield productivity was obtained from K1cp application with $62 \mathrm{t} \mathrm{ha-1}$. It was followed by K2cP, K3cp and K4cp applications, in order, with yield productivity values of $55 \mathrm{t} \mathrm{ha}^{-1}$, $36 \mathrm{t} \mathrm{ha}^{-1}$ and $24 \mathrm{t} \mathrm{ha}^{-1}$, respectively. As expected, the minimum yield productivity $\left(18 \mathrm{t} \mathrm{ha}^{-1}\right)$ was found from control $\mathrm{K} 5_{\mathrm{cp}}$ application in which irrigation was not applied. The yield productivity of unirrigated $\mathrm{K} 5$ ср application was lower at a rate of $244.4 \%$ in a comparison with $\mathrm{K} 1$ cp application. Moreover, lower yield productivity levels at a rate of $12.7 \%, 72.2 \%$ and $158.3 \%$ from $\mathrm{K} 2{ }_{\mathrm{cp}}$, $\mathrm{K}_{\mathrm{cp}}$ and $\mathrm{K} 4_{\mathrm{cp}}$ applications were observed in a comparison with $\mathrm{K}_{\mathrm{cp}}$ application, respectively (see Table 4).

Table 3. Relationship between the decrease in relative water use and decrease in relative yield and yield response factor for drip-irrigated eggplant.

Çizelge 3. Damla sulama ile sulanan patııcan için oransal su kullanımındaki azalma ile oransal verim ve verim tepki faktöründeki azalma arasındaki ilișki.

\begin{tabular}{ccccccccc}
\hline $\begin{array}{c}\text { Irrigation } \\
\text { treatment }\end{array}$ & $\begin{array}{c}\text { Yield } \\
\left(\mathrm{t} \mathrm{ha} \mathrm{C}^{-1}\right)\end{array}$ & $\begin{array}{c}\text { Applied Water } \\
(\mathrm{mm})\end{array}$ & $\mathrm{ET}_{\mathrm{a}}(\mathrm{mm})$ & $\mathrm{ET}_{\mathrm{a}} / \mathrm{ET}_{\mathrm{m}}$ & $\mathrm{Y}_{\mathrm{a}} / \mathrm{Y}_{\mathrm{m}}$ & $1-\left(\mathrm{ET}_{\mathrm{a}} / \mathrm{ET}_{\mathrm{m}}\right)$ & $1-\left(\mathrm{Y}_{\mathrm{a}} / \mathrm{Y}_{\mathrm{m}}\right)$ & $\mathrm{k}_{\mathrm{y}}$ \\
\hline $\mathrm{K} 1_{\mathrm{cp}}$ & 62 & 464 & 472 & 1.000 & 1.000 & 0.000 & 0.000 & 0.000 \\
$\mathrm{~K} 2_{\mathrm{cp}}$ & 55 & 348 & 418 & 0.909 & 0.887 & 0.091 & 0.113 & 1.239 \\
$\mathrm{~K} 3_{\mathrm{cp}}$ & 36 & 232 & 302 & 0.640 & 0.581 & 0.360 & 0.419 & 1.164 \\
$\mathrm{~K} 4_{\mathrm{cp}}$ & 24 & 116 & 219 & 0.463 & 0.387 & 0.537 & 0.613 & 1.141 \\
$\mathrm{~K} 5_{c \mathrm{p}}$ & 18 & 85 & 170 & 0.360 & 0.290 & 0.640 & 0.710 & 1.109 \\
\hline
\end{tabular}
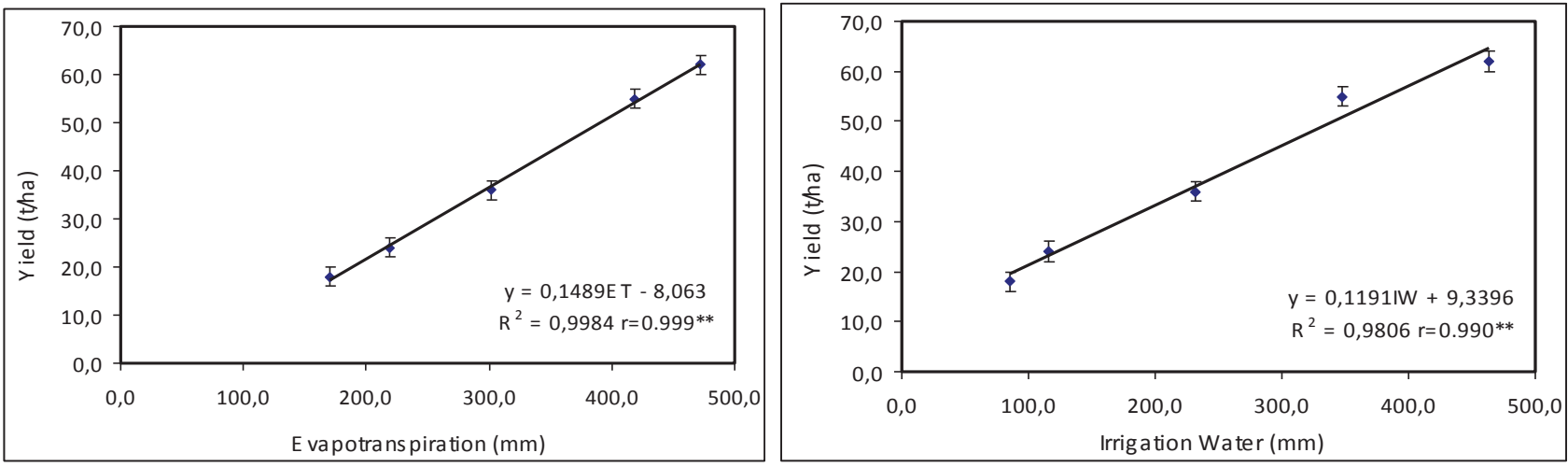

Figure 2. The relationship between crop evapotranspiration with yield and water irrigation with yield. (The errors bars are SE of 10 plants)

Șekil 2. Verim ile bitki su tüketimi ve verim ile sulama suyu arasındaki ilișki (Hata çubukları 10 bitkinin SE standart hata değeridir). 
Table 4. Effects of irrigation treatments on eggplant marketable parameters.

Çizelge 4. Sulama uygulamalarının patlıcanın pazarlanabilir parametreleri üzerine etkisi.

\begin{tabular}{|c|c|c|c|c|c|}
\hline Irrigation treatment & Fruit length (cm) & Fruit diameter $(\mathrm{cm})$ & Fruit weight (g) & Dry matter (\%) & Yield $\left(\mathrm{t} \mathrm{ha}^{-1}\right)$ \\
\hline $\mathrm{K} 1_{\mathrm{CP}}$ & $24.5 a$ & 8.0a & $230 a$ & $8.0 d$ & $62 a$ \\
\hline $\mathrm{K} 2_{\mathrm{CP}}$ & 23.0a & $7.5 a$ & $222 a$ & $10.4 c$ & $55 b$ \\
\hline $\mathrm{K} 3_{\mathrm{CP}}$ & $20.0 a$ & 6.5ab & $202 a$ & $12.1 \mathrm{bc}$ & $36 c$ \\
\hline $\mathrm{K} 4_{\mathrm{CP}}$ & 17.0a & 5.5ab & 186ab & 13.8ab & $24 d$ \\
\hline $\mathrm{K} 5_{\mathrm{CP}}$ & $9.5 b$ & $4.0 \mathrm{c}$ & $144 b$ & $14.2 a$ & $18 d$ \\
\hline Treatments & ** & ** & ** & ** & ** \\
\hline Blocks & $* *$ & ns & ns & ns & ns \\
\hline
\end{tabular}

** Correlation is significant at the 0.01 level, * Correlation is significant at the 0.05 level, ns non-significant

Crop yields and quality are reduced due to water deficits applied particularly three or four weeks before harvest. Fruit length and fruit weight were significantly influenced by deficit irrigation, while the values of $\mathrm{K}_{\mathrm{cp}^{\prime}}, \mathrm{K} 2_{\mathrm{cp}^{\prime}} \mathrm{K} 3_{\mathrm{cp}^{\prime}}$ $\mathrm{K} 4_{\mathrm{cp}}$ and $\mathrm{K} 5_{\mathrm{cp}}$ treatments were each located in a different statistical group. It may be concluded

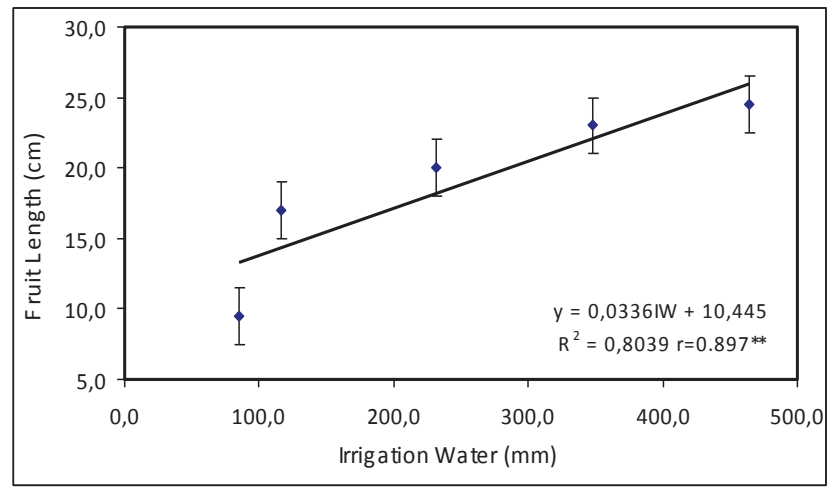

(a)
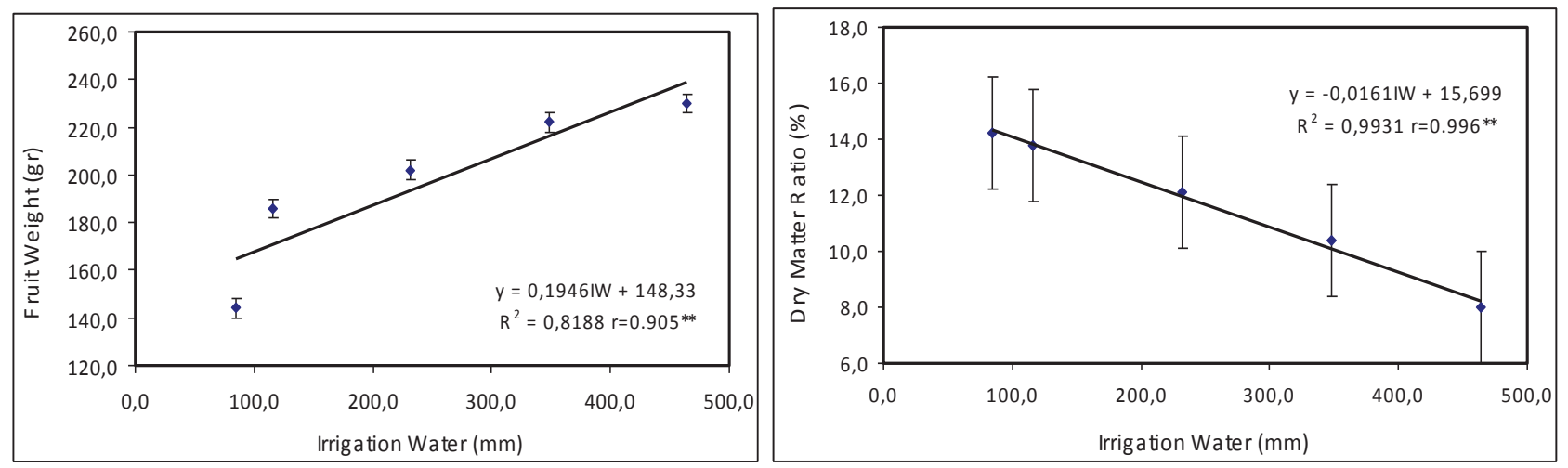

(c) that significant reduction in fruit diameter was not observed with the deficit of applied irrigation water (25\%). A high level of linear relationship was determined between fruit diameter, length and weight, whereas negative linear relation was found between dry matter and amount of water applied (IW). The related equations were

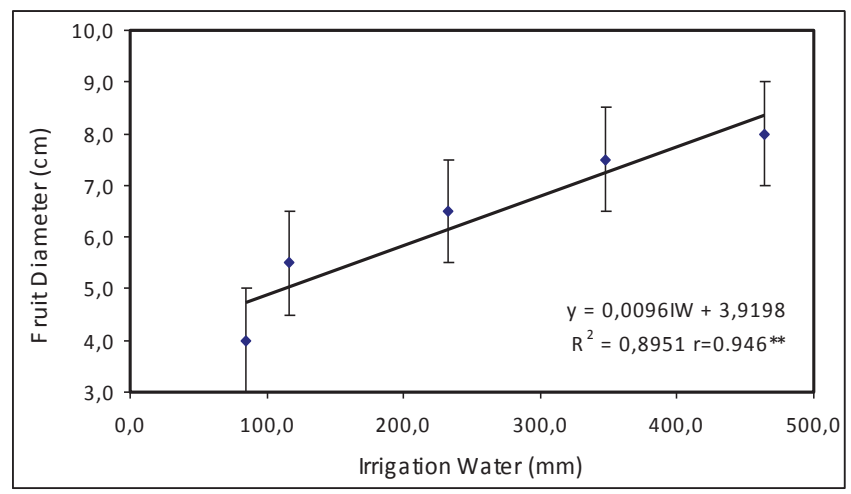

(b)

(d)

Figure 3. Relationship between applied irrigation water and fruit length (a), diameter (b), weight (c) and dry matter (d). (The errors bars are SE of 10 plants)

Șekil 3. Uygulanan sulama suyu ile meyve boyu (a), çapı (b), ağırlığı (c) ve kuru madde (d) arasındaki ilișki (Hata çubukları 10 bitkinin SE standart hata değeridir). 
as follows; fruit length $=0.0336 \mathrm{IW}+10.445$ with $R_{2}=0.80$ (Fig. 3.a), fruit diameter $=0.0096 \mathrm{IW}+$ 3.9198 with $R_{2}=0.90$ (Fig. 3.b.), fruit weight $=$ $0.1946 \mathrm{IW}-148.33$ with $R_{2}=0.82$ (Fig. 3.c.), and dry matter $=-0.0161 \mathrm{IW}+15.699$ with $R_{2}=0.99$ (Fig. 3.d.).

Crop yield response factor $\left(\mathbf{k}_{\mathrm{y}}\right)$ : Linear relationship between proportional decrease in water consumption and proportional decrease in yield productivity is depicted with crop yield productivity response factor $\left(k_{y}\right)$ that represents yield productivity response to be lowered in water consumption. In other saying, it explains the decrease in yield productivity in relation with the decrease in water consumption per unit (Stewart et al., 1975; Doorenbos and Kassam, 1979). For irrigation application, seasonal yield productivity response factor $\left(k_{y}\right)$ was calculated as 1.14 (see Fig. 4). $k_{y}$ values increased with parallel to increase in water amount, except $\mathrm{K} 5_{\mathrm{cp}}$ application.

1-(E Ta/E Tm)

$\begin{array}{llllllll}0,700 & 0,600 & 0,500 & 0,400 & 0,300 & 0,200 & 0,100 & 0,000\end{array}$

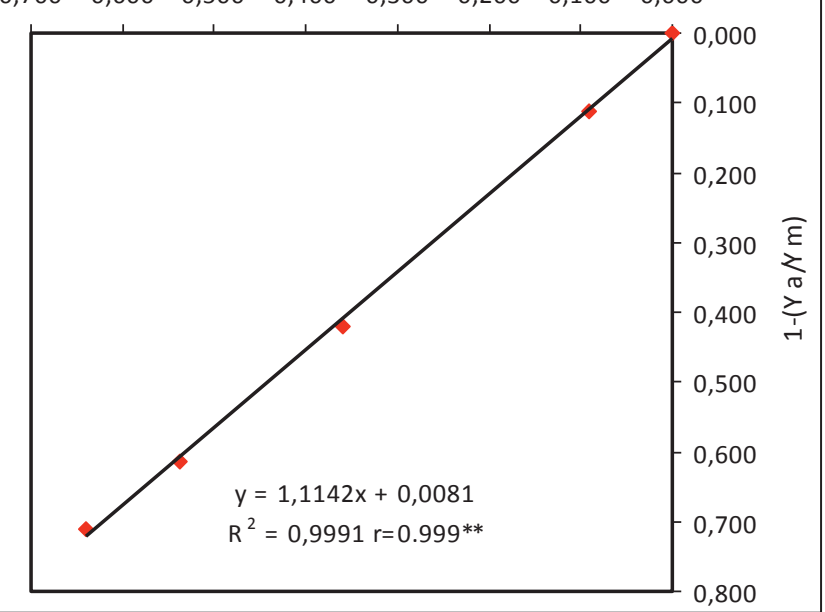

Figure 4. Relationship between relative yield decrease and relative crop evapotranspiration decrease for eggplant throughout the total growing season

Șekil 4. Toplam büyüme mevsimi boyunca patıcanda oransal bitki su tüketimindeki azalma ile oransal verimdeki azalma arasındaki ilișki.

Water use efficiencies: Values of WUE and IWUE was lowered when the amount of irrigation water was reduced. The highest WUE and IWUE values were calculated from K2cp application as 13.16 and $10.63 \mathrm{~kg} \mathrm{~m}^{-3}$, respectively. IWUE value of K2cP application was found higher than other applications as $\mathrm{Klcp}, \mathrm{K} 3 \mathrm{cP}, \mathrm{K} 4 \mathrm{cp}$ and $\mathrm{K} 5 \mathrm{cp}$, in order (See Table 5).
Table 5. Total water use efficiency (WUE) and irrigation water use efficiency (IWUE) values for drip- irrigated eggplant at different irrigation treatments.

Çizelge 5. Farklı sulama uygulamalarında damla sulama ile sulanan patlıcan için toplam su kullanım randımanı (WUE) ve sulama suyu kullanım randımanı değerleri.

\begin{tabular}{cccc}
\hline $\begin{array}{c}\text { Irrigation } \\
\text { treatment }\end{array}$ & $\begin{array}{c}\text { Yield } \\
\mathrm{t} \mathrm{ha}^{-1}\end{array}$ & $\begin{array}{c}\text { WUE } \\
\mathrm{kg} \mathrm{m}^{-3}\end{array}$ & $\begin{array}{c}\text { IWUE } \\
\mathrm{kg} \mathrm{m}^{-3}\end{array}$ \\
\hline $\mathrm{K} 1_{\mathrm{cp}}$ & 62 & 13.14 & 9.48 \\
$\mathrm{~K} 2_{\mathrm{cp}}$ & 55 & 13.16 & 10.63 \\
$\mathrm{~K} 3_{\mathrm{cp}}$ & 36 & 11.92 & 7.76 \\
$\mathrm{~K}_{\mathrm{cp}}$ & 24 & 10.98 & 5.17 \\
$\mathrm{~K}_{\mathrm{cp}}$ & 18 & 10.59 & 0.00 \\
\hline
\end{tabular}

\section{DISCUSSION}

Chartzoulakis and Drosos (1999) reported that the water requirements of eggplant ranged between $150 \mathrm{~mm}$ and $380 \mathrm{~mm}$. Eliades (1992) stated that the eggplant could grow with as low as 285 mm of water. Aujla et al. (2007) stated that required irrigation water amount of eggplant ranged between 618 and $1051 \mathrm{~mm}$, the seasonal evapotranspiration was between 815 and 1222 $\mathrm{mm}$. When irrigation water was applied to eggplant at the $10 \mathrm{~mm}$ of pan evaporation, the highest evapotranspiration $(800 \mathrm{~mm})$ was observed in a study of (Chiaranda and Zerbi, 1986). Ertek et al. (2006) also found that applied irrigation water amounts for each treatment ranged from 372 to $689 \mathrm{~mm}$, while average evapotranspiration values changed between 420 and $689 \mathrm{~mm}$. Irrigation water $(1276 \mathrm{~mm})$ was applied to full irrigation (100\% refill of A pan evaporation) treatment of drip-irrigated eggplant in Southeastern part of Turkey, and the seasonal water amount for eggplant changed between 905 and $1373 \mathrm{~mm}$ in the same study (Kırnak et al., 2002). In their study for eggplant production in soilless culture, the average water consumption of eggplant was found as low as $290 \mathrm{~mm}$ under Mediterranean climate conditions (Hamdy et al., 2002). Seasonal crop water consumption for eggplant yield ranged from 452 mm - 696 mm (Ertek et al., 2002). In our study, irrigation water applied to eggplants changed between 85 and $464 \mathrm{~mm}$, and water consumption changed between 170 to 472 $\mathrm{mm}$ for eggplants. These results are notably in accordance with the irrigation water amounts and crop water consumption values obtained from previous studies (Eliades, 1992; Chartzoulakis and Drosos, 1999; Ertek et al., 2006). 
The eggplant yield changed between 18 $\mathrm{t} \mathrm{ha} \mathrm{A}^{-1}$ and $62 \mathrm{t} \mathrm{ha}^{-1}$. Based on to the results of this study, a significant effect of deficit irrigation was observed on fruit yield. This result is in agreement with those of /Chartzoulakis and Drosos, 1999; Ertek at al., 2002; Ertek et al., 2006; Aujla et al., 2007; Lovelli et al., 2007; Ünlükara et al., 2008). Previous researches have presented similar results under different irrigation regimes (Ertek et al., 2006; Aujla et al., 2007; Michalojc and Buczkowska, 2009). Yield was considerably lowered as the amount of irrigation water reduced. Quality parameters such as fruit diameter, length and weight have produced a similar response to deficit irrigation as observed at yield. As expected, all irrigation treatments had higher values than the non-watered (K5cp) treatment. These values are similar to those of (Kara et al., 1996; Ertek et al., 2006; Lovelli et al., 2007; Karam et al., 2009; Șenyiğit et al., 2011 ). Since K $1 \mathrm{cP}$ treatment has higher fruit weight than the other treatments, the lowest dry matter was found at $\mathrm{K} 1_{\mathrm{cp}}$ treatment when the highest was observed at $\mathrm{K} 5$ cp treatment. We may conclude that significant increases in dry matter may be experienced by the increasing level of irrigation water deficit. These results are in agreement with those of (Ertek et al., 2006; Lovelli et al., 2007; Aujla et al., 2007).

WUE and IWUE values varied from 10.59 to 13.16 and from 0.00 to 10.63 , respectively. $K 2_{\text {cp }}$ treatment has delivered the highest WUE and IWUE with 13.16 and $10.63 \mathrm{~kg} \mathrm{~m}^{-3}$, respectively. When the results regarding water use efficiency are compared with the findings of different researchers, they were found to be similar (Kara et al., 1996; Ertek et al., 2002; Lovelli et al., 2007; Dutta and Tafardar, 2008). Eggplant variety choice, climate, soil structure and effective use of water also affect these values. Crop yield response factor $\left(k_{y}\right)$ was calculated as 1.14. The specified value of $k_{y}(1.14)$ which is greater than 1.00 shows that eggplant is susceptible to the water. Crop yield response factor $\left(k_{y}\right)$ also coincides with the values found by researchers who studied on similar issues (Kara et al., 1996; Lovelli et al., 2007; Dutta and Tafardar, 2008; Karam et al., 2009).

\section{CONCLUSIONS}

The ultimate goals of optimum irrigation management strategies in deficit areas are to enhance yield and quality as much as possible, increase WUE and reduce water consumption. $\mathrm{K} 2_{c p}$ treatment allowed high yield and quality (in terms of fruit length, diameter and weight), increased WUE and reduced water use. The variety choice of eggplant, climate and soil structure also influenced to change WUE and IWUE values. Crop yield response factor of eggplant (1.14) which is greater than 1.00 shows that eggplant is susceptible to the water. $K Z_{\text {cp }}$ application (75\%) can be recommended as the most effective irrigation level for the eggplants to which drip irrigation is applied under scarce water resource and unheated greenhouse conditions.

\section{REFERENCES}

Aldrich R A, Barto J W (1989). Greenhouse Engineering. Northeast Regional Agricultural Engineering Service, Cooperative Extension, Ithaca, NY.

Anonymous (2003). Meteoroloji Bülteni (in Turkish). Devlet Meteoroloji İșleri Genel Müdürlüğü, Bașbakanlık Basımevi, Ankara, pp. 111-112 (In Turkish).

AOAC (Association of Official Analytical Chemistry) (2000). Official Methods of Analysis, 17th ed. AOAC, Washington, DC, USA.

Aujla M S, Thind HS, Buttar G S (2007). Fruit yield and water use efficiency of eggplant (Solanum melongema L.) as influenced by different quantities of nitrogen and water applied through drip and furrow irrigation. Sci. Horti. 112 : 142-148.

Ayas S, Demirtaș C (2009). Deficit irrigation effects on cucumber (Cucumis sativus L. Maraton) yield in unheated greenhouse condition. Journal of Food, Agriculture \& Environment Vol. 7 (3\&4): 645-649.

Ayas S, Demirtas C (2009). Deficit irrigation effects on onion (Allium cepa L. E.T. Grano 502) yield in unheated greenhouse condition. Journal of Food, Agriculture \& Environment Vol. 7(3\&4): 239 - 243.

Ayas S, Korukcu A (2010). "Water-yield relationships in deficit irrigated potato. Journal of Agricultural Faculty of Uludag University, Cilt 24, Sayı 2, 23-36.

Ayas S, Orta H, Yazgan S (2011). Deficit irrigation effects on Broccoli (Brassica oleracea L. var. Monet) yield in unheated greenhouse condition. Bulgarian Journal of Agricultural Science. 17(4): 551- 559.

Ayas S (2013). The effects of different regimes on Potato (Solanum Tuberosum L. Hermes) yield and quality characteristics under unheated greenhouse conditions. Bulgarian Journal of Agricultural Science, 19 (No1) 2013, 87-95.

Bar-Yosef B, Sagiv B (1982). Response of tomatoes to $\mathrm{N}$ and water applied via a trickle irrigation system. II Water. Argon. J 74:637-639.

Behboudian M H (1977). Responses of eggplant to drought. I. Plant water balance. Scientia Hortic. 191:149156. 
Bogle C R, Hartz T K, Nuntoez C (1989). Comparison of subsurface trickle and furrow irrigation on plastic mulched and bare soil for tomato production. J. Am. Soc. Hortic. Sci. 114:40-43.

Buyukcangaz $\mathrm{H}$, Yazgan S, Ayas S, Candogan B N, Ayas $F$ (2008). Effects of deficit irrigation on yield and quality of unheated greenhouse grown green bean. Journal of Food, Agriculture \& Environment Vol. 6(2): 168-172.

Chartzoulakis K, Drosos N (1999). Irrigation requirements of greenhouse vegetables in Crete. Cahiers Options Mediterraneennes, 31:215-221.

Chiaranda F O, Zerbi G (1986). Water requirements of eggplant grown under a greenhouse. Acta Hortic. 191:149156.

Clough G H, Locasio S J and Olsen S M (1990). The yield of successively cropped polyethylene-mulched vegetables as affected by irrigation method and fertilization management. J. Am. Soc. Hortic. Sci. 115:884-887.

Demirtas C, Ayas S (2009). Deficit irrigation effects on pepper (Capsicum annuum L. Demre) yield in unheated greenhouse condition. Journal of Food, Agriculture \& Environment Vol. 7 (3\&4): 989 - 993.

Doorenbos J, Pruitt WO (1977). Guidelines for Predicting Crop Water Requirements. FAO Irrigation and Drainage Paper No. 24, Food and Agricultural Organization of the United Nations, Rome.

Doorenbos J, Kassam A H (1979). Yield Response to Water. FAO Irrigation and Drainage Paper No. 33, Rome.

Dutta D and Tafardar P K (2008). Crop-Water Productivity of Eggplant Solanum melongena L.) as Influenced by Irrigation and Mulch in Semi-Arid Region of West Bengal, India. Department of Agronomy, Department of Soil and Water Conservation, Bidhan Chandra Krishi Viswavidyalaya (BCKV), Mohanpur-741252, Nadia, West Bengal, India.

Eliades $G$ (1992). Irrigation of eggplants grown in heated greenhouses. J. Hort. Sci., 67(1):143-147.

Enoch H Z, Enoch Y (1 999). The history and geography of greenhouse. In Stanhil, G and Enoch, H Z (eds). Greenhouse Ecosystems. Ecosystems of the World 20. Elsevier, Amsterdam, pp. 1-15.

Ertek A, Șensoy S, Yıldız M, Kabay T (2002). Açık su yüzeyi buharlașmasından yararlanılarak sera koșullarında patıcan bitkisi için en uygun su miktarı ve sulama aralığının belirlenmesi. KSU J. Science and Engineering 5(2):57-67.

Ertek A, Șensoy S, Küçükyumuk C, Gedik i (2006). Determination of plant-pan coefficients for field-grown eggplant (Solanum Melongena L.) using class A pan evaporation values. Agricultural Water Management 85: 58-66.

FAO (2013). (http://mww.tuik.gov.tr/PreTablo.do?alt_ $\mathrm{id}=1001)$.

GraafR, EndeJ(1981). Transpirationandevapotranspiration of the glasshouse crops. Acta Hort. 119:147-158.

Hamdy A, Chouaib W, Pacucci G (2002). Eggplant production in soilless culture under saline irrigation practices and soil conditioner application. Acta Hort. 633.
Hartz T K (1993). Drip irrigation scheduling for fresh market tomato production. HortScience 28:35-37.

Howell T A, Cuenca R H, Solomon K H (1990). Crop yield response. Chapter 5 in Management of Farm Irrigation Systems, pp. 93-122. Edited by G. J. Hoffman, T. A. Howell, and K. H. Solomon. ASAE Monograph, ASAE, St. Joseph, Michigan. 1040 pp.

Kanber R (1984). Çukurova Koșullarında Açık Su Yüzeyi Buharlașmasından Yararlanarak Birinci ve İkinci Ürün Yerfıstığının Sulanması. Bölge Topraksu Arșt. Enst. Yay. 114 (64), 93, Tarsus.

Kara C, Gündüz M, Sipahi N (1996) Köy Hizmetleri Genel Müdürlüğü. Șanlıurfa Araștırma Enstitüsü Müdürlüğü Yayınları. Genel Yayın No: 108, Rapor Serisi No:79.

Karam F, Saliba R, Skaf S, Breidy J, Rouphael Y, Balendock J (2009). Yield and Water Use of Eggplants (Solanum melongena L.) Under Full and Deficit Irrigation Regimes. Agricultural Water Management 98:1307-1316.

Kırnak H, Ismail T, Cengiz K, David H (2002). Effects of deficit irrigation on growth, yield and yield quality of eggplant under semi-arid conditions. Aus. Jour. of Agri. Res. 53(12): 1367-1373.

Locascio S J, Smajstrla A G (1996). Water application scheduling by pan evaporation for drip-irrigated tomato. Journal of the American Society for Horticulture Science $121(1): 63-68$.

Lorenz O A, Maynard D N (1980). Knott's Hand Book for Vegetable Growers. 2nd edt. John Wiley Sons, New York.

Lovelli S, Perniola M, Ferrara A, Di Tommaso T (2007). Yield response factor to water (ky) and water use efficiency of Carthamus Tinctorius L. and Solanum Melongena L. Agricultural Water Management 92: 73-80.

Mahajan G and Singh K G (2006). Response of Greenhouse tomato to irrigation and fertigation. Agricultural Water Management. 84:202-206.

McNeish C M, Welch N C, Nelson R D (1985). Trickle irrigation requirements for stawberries in coastal California. J. Am. Soc. Hortic. Sci. 110:714-718.

Michalojc Z, Buczkowska H (2009). Influence of varied potassium fertilization on eggplant yield and fruit quality in plastic tunnel cultivation. Folia Horticulturae 21/1: 17-26.

Ritchie J T, Johnson B S (1990). Irrigation of agricultural crops. Agronomy Monograph no. 30, pp. 363-390.

Șenyiğit $U$, Kadayıfçı A, Özdemir F O, Öz H, Atılgan A (2011). Effects of Different Irrigation Programs on Yield and Quality Parameters of Eggplant (Solanum melongena L.) Under Greenhouse Conditions Department of Agricultural Structure and Irrigation, Faculty of Agriculture, Süleyman Demirel University, No: 32260, Isparta.

Steel R G D, Torrie J H (1980). Principles and Procedures of Statistics. A Biometrical Approach. McGraw-Hill, NewYork, pp. 186-187.

Stewart J I, Misra R D, Pruitt W O, Hagan R M (1975). Irrigating corn and sorghum with a deficient water supply. Trans. ASAE, 18:270-280. 
Ünlükara A, Kurunç A, Kesmez G D, Yurtseven E, Suarez D (2008). Effects of salinity on eggplant (Solanum melongena L.) growth and evapotranspiration. Irrig. and Drain.DOI: 10.1002/ird.453.

Von Elsner B, Briassoulis D, Waaijenberg D, Mistriotis A, Von Zabeltizt C H R, Gratraud J (2000). Mechanical properties of covering materials for greenhouses. Part I. General overview. J. Agric. Eng. Res. 67:81-96.
Yazgan S, Ayas S, Demirtas C, Buyukcangaz H, Candogan B N (2008). Deficit irrigation effects on lettuce (Lactuca sativa var. Olenka) yield in unheated greenhouse condition. Journal of Food, Agriculture \& Environment 6(2):168-172.

Yuan B Z, Sun J, Nishiyama S (2003). Effect of drip irrigation on strawberry growth inside a plastic greenhouse. Biosystems Engineering 87 (2):237-245. 